\title{
Prevention of Catheter-Related Bloodstream Infections in Patients on Hemodialysis
}

\author{
Dulce Barbosa, Mônica Taminato, Dayana Fram, \\ Cibele Grothe and Angélica Belasco \\ Federal University of São Paulo/UNIFESP
}

Brazil

\section{Introduction}

Fourteen percent of deaths among patients with endstage kidney disease (ESKD) are due to infections, preceded only by cardiovascular diseases (USRDS,2006). According to The United States Renal Data System (USRDS), the number of patients receiving hemodialysis in the United States of America (USA) was 328,000 in 2006(USRDS,2008). Secondary to multiple defects in the ability to kill bacteria, infectious complications are more frequent in the Chronic Kidney Disease (CKD) and dialysis populations. (USRDS,2010).

Data from Brazilian Society of Nephrology reported that the number of patients on dialysis treatment in Brazil was 77.589 in 2009 and $90.8 \%$ of those patients were receiving hemodialysis (SBN,2010). The estimated prevalence and incidence rates of chronic renal failure on maintenance dialysis were 405 and 144 patients per million population, respectively. The estimated number of new patients starting dialysis program in 2010 was 49,077 . The annual gross mortality rate was $17.1 \%$. For prevalent patients, $39.9 \%$ were aged 60 years or older, $89.6 \%$ were on hemodialysis and $10.4 \%$ on peritoneal dialysis, 30,419 $(39.2 \%)$ were on a waiting list of renal transplant, $27 \%$ were diabetics, $37.9 \%$ had serum phosphorus $>5.5 \mathrm{mg} / \mathrm{dL}$ and $42.8 \%$ hemoglobin $<11 \mathrm{~g} / \mathrm{dL}$. A venous catheter was the vascular access for $12.4 \%$ of the hemodialysis patients.

$\mathrm{CVC}(\mathrm{CVC})$ as vascular access are considered inferior to other means of vascular access with $2006 \mathrm{~K} / \mathrm{DOQI}$ guidelines recommending less than 10\% prevalence rate. However, despite these recommendations the Dialysis Outcomes and Practice Patterns Study (DOPPS II), reports that $46 \%$ to $70 \%$ of European and Canadian ESKD patients commencing maintenance haemodialysis do so via a CVC. This dependence on CVC is also reflected in the prevalence rates which range from 18\% (Europe) to 34\% (Canada) (Mendelssohn DC 2006 ). This over reliance on catheters may be attributed to late referrals to nephrologists, delay in access formation, lack of sufficient time for an AVF to mature or an ever increasing older ESKD population who experience higher rates of vascular disease and diabetes resulting in an inadequate vasculature for AVF formation (Butterly DW 2001 ; Letourneau I 2003 ; Mendelssohn DC 2006 ).

Data from the USA National Healthcare Safety Network demonstrated that bloodstream infection rates in 2006 varied according to the site of vascular access: $0.5 \%$ arteriovenous 
fistula (AVF), $0.9 \%$ AV grafts, $4.2 \%$ long-term central venous catheter and $27.1 \%$ short-term central venous catheter per month, respectively.

Chronic kidney disease (CKD) is a syndrome caused by many diseases that have in common the progressive reduction of glomerular filtration. Regardless of the initial insult caused by the underlying disease, the lesion progresses to glomerulosclerosis and interstitial fibrosis, resulting in established chronic kidney disease (ECKD). The ECKD treatment depends on the evolution of the disease and may be conservative with medication use, diet and fluid restriction, when such treatment becomes insufficient, you need to start dialysis to replace, in part, the kidney's function, or even apply to a kidney transplant (Mason J et al, 2008).

Conservative treatment aims to help reduce the rate of progression of the renal disease, using the dietary guidelines that aim to promote adequate nutritional status, metabolic control and uremic symptoms (20), with the improvement in organ dysfunction and comorbid conditions such as infection, contributing to better outcomes related to dialysis and transplantation (Klevens RM et al, 2008).

Despite advances in dialysis mortality remains high in ECKD. The infection continues to be a major cause of morbidity and the second most frequent cause of mortality (14\%), preceded only by cardiovascular events as the first cause of death (Klevens RM et al, 2008).

Most microorganisms detected in the blood culture were considered to be a skin contaminant coagulase-negative Staphylococcus. Forty two percent (42\%) of Staphylococcus aureus were resistant to methicillin and 39\% of Enterococcus spp were resistant to vancomycin (Klevens et al,2008). Patients receiving hemodialysis have high risk for infection due to immunosuppression caused by ESKD, comorbidities, inadequate diet and the need for maintaining the venous access for long periods. In dialysis clinics many patients are submitted to this procedure at the same time, leading to the dissemination of microorganisms through direct or indirect contact with the devices, equipment, contaminated surfaces or the hands of health professionals.

In a study conducted at the Federal University of São Paulo (UNIFESP) it was found an incidence of infection of the bloodstream of $61 \%$ among patients with ESKD in use of central venous catheter associated with a mortality rate of $29 \%$ (Grothe C et al, 2009).

American data show that the main agents of bloodstream infections in hemodialysis patients were methicillin-resistant Staphylococcus aureus (MRSA), Staphylococcus coagulase negative (SCN) and vancomycin-resistant Enterococcus spp (VRE) (Klevens RM, 2008).

S. aureus is an important etiologic agent of both community-acquired infections and healthcare associated infections (HAI). In community-acquired infections are responsible for infections of skin and soft tissues, but is also responsible for invasive infections such as pyomyositis, osteomyelitis, necrotizing fasciitis, pneumonia and severe sepsis (King MD et al, 2006; Bocchini CE et al 2006; PV Adem et al , 2005). This agent is an important colonizer of the skin and mucous membranes. Although many sites of the human body can be colonized, nasal colonization is the most common. Studies show that approximately $20 \%$ of health professionals have persistent colonization and $80 \%$ intermittent colonization by this microorganism, nasal colonization is the biggest risk 
factor for the development of most endogenous infections (Van Belkum A et al, 2009 ; Wertheim HF et al, 2004; Von Eiff C et al, 2001).

Following the acquisition of MRSA colonization during hospitalization, patients with chronic renal failure on conservative treatment may persist as carriers for prolonged periods even after discharge from hospital and readmittance, may reintroduce the bacteria in the hospital (Roberts S et al, 2004)

The risk of transmission occurs most often because the patient is not identified as a carrier. A retrospective analysis that used information from hospital patients for eight years evaluated the risk of acquiring MRSA in patients who shared the same room with other hospital patients colonized with MRSA, unidentified. The study found a 13\% incidence of infection by the same strain of MRSA among colonized patients (Moore $C$ et al, 2008). Another study that evaluated the prevalence of MRSA on admission identified that $49 \%$ of patients would not have been identified without screening on admission (VCC Cheng et al, 2008).

Faced with complications that occurred due to infection in patients on dialysis treatment, Barbosa et al (D Barbosa et al, 2004; MCS Freitas et al, 2006) assessed the prevalence of colonization by vancomycin-resistant Enterococcus (VRE) in 300 patients in program dialysis and 280 transplant recipients treated in this service. It was found a prevalence rate of $14.5 \%$ in dialysis patients and $14 \%$ in renal transplanted patients, which proves to be quite high in relation to the rate documented in American services, which is around $7 \%$ (Tokars JI et al, 2000). The molecular typing of these samples was recently performed and it made possible the important detection of cross-transmission of VRE among patients treated at the Department of Dialysis and Transplantation of UNIFESP, and Fram et al observed the occurrence of vancomycin-resistant Enterococcus (VRE) crosstransmission between two patient groups (long-term dialysis and kidney transplant patients) Fram D et al, 2010.

In Europe and the United States the increase in infections caused by VRE in patients with ESKD have contributed to an increased morbidity and mortality in this patients population, which has generated a great concern in the nephrology services (Perencevich EM et al, 2004). Data from the National Healthcare Safety Network show that VRE was isolated in $26 \%$ of dialisys patients' blood cultures (Rom Klevens, 2008).

In the 90s, there was a significant increase in the prevalence of VRE infection in hospitals, particularly among immunosuppressed patients, such as those with chronic diseases, infectious diseases and renal transplants (Brady JP et al, 1998). Currently, VRE is between the second and third most frequent cause in the IRAS, due to its rapid spread, high associated mortality and limited treatment options, besides the possibility of transfer of the vanA resistance gene to other virulent organisms and more prevalent as the $S$. aureus (Chang S et al, 2003; \& Salgado CD Farr BM, 2003).

The glycopeptide resistance may be mediated by several genes, vanA, vanB, vanC, vanD, vanE, van $G$ and vanL. Resistance mediated by mobile elements, called plasmids, may be transferred from one strain of VRE to another (Werner G et al, 2008; Arthur M, 1993)

The increased risk of VRE colonization and infection has been associated with the indiscriminate use of antibiotics, prolonged hospital stay, underlying diseases, transplantation, invasive treatments such as intra-abdominal surgery, presence of central 
venous catheterization and proximity to colonized patients. Studies done in the UNIFESP's nephrology service demonstrated the presence of VRE in dialysis patients and kidney transplantation. Among dialysis patients, the colonization prevalence was $14.5 \%$ and the identified risk factors were: dialysis type (hemodialysis), number of hospitalizations and length of hospital stay. Similar rate was found among patients undergoing renal transplantation, where the prevalence was $14 \%$, although no risk factor was identified (Barbosa D et al, 2004; MCS Freitas et al, 2006).

Considering the emergence of new microorganisms, Klebsiella pneumoniae producing carbapenemases (KPC) has been highlighted as an important pathogen in healthcare related infections. Due to the great ability to spread and limited therapeutic options, the introduction of surveillance of this pathogen in the study group is necessary. According to a recent study by Ji-Young Rhee (2010), the isolation of bacteria K. pneumoniae producing carbapenemases (KPC) in hemodialysis patients with chronic renal failure demonstrated that the infection caused by multidrug-resistant pathogen that affected the patient's prognosis. Another study in Chicago showed that the implementation of a bundle that includes: surveillance cultures, team education, contact precautions, chlorhexidine bathing and environment cleaning greatly reduced the horizontal transmission of this pathogen (Mimoz O, 2007).

Microbial resistance should be considered because patients on dialysis treatment are often hospitalized and exposed to multi-resistant microorganisms and to broadspectrum antimicrobial therapy. (Klevens et al, 2008; Fram et al, 2010; Horl Wh 1999;DescampsLatscha B \& Herbelin A, 1993; MMWR,2001). On the one hand, the quality of dialysis and thus patients. well being and survival depend on the venous access; on the other hand, this is considered the major risk factor for infection and especially bacteremia in this group of patients(Mangini et al, 2005). In a study performed at Universidade Federal de São Paulo, $61 \%$ of patients with ESKD using central venous catheter presented bacteremia. Risk factors for bacteremia were: catheter insertion in the subclavian vein, duration of catheter use and the hospitalization period. The mortality rate in these patients was $29 \%$ and for patients who developed endocarditis it was 55.5\%(Groethe $\mathrm{C}$ et al, 2010). As this population is exposed to a high infection risk which can be prevented in most cases by health professionals, a systematic review of literature was performed to establish standard measures to prevent catheter associated infections in hemodialysis patients.

\subsection{Epidemiology}

Twenty months of epidemiological surveillance data in the USA demonstrated that the risk for bacteremia was 32 times higher when short-term venous catheter was used, and 19 times higher when long-term venous catheter was used compared to the use of arteriovenous fistula (AVF). Similar data were observed in a study conducted in 11 dialysis centers in Canada (George A et al, 2006). A prospective survey with 35,000 randomized patients between the years of 1996 and 2007 treated in about 300 dialysis units in 12 countries demonstrated a great variation on AVF utilization. AVF use declined in elderly, obese, diabetic and patients with cardiovascular diseases or recurrent cellulitis. Considering the high mortality caused by the use of catheters, the best option for these patients is AV graft. However, in some countries there was an increase in catheter use and a proportional decrease in the use of AV grafts in patients with the characteristics mentioned (LoboRD et 
al, 2005). Measures to prevent catheter associated infections in hemodialysis patients must be considered taking into account the reduction in the use of central venous catheter (CVC), giving priority to the use of AVF whenever possible. However, in patients with impaired vessels, obesity and diabetes, where access through AVF or graft can be difficult, long-term CVC use is recommended(MMWR, 2001).

\section{Methods}

The present study was carried out through a review of the literature encompassing the issue of preventing catheter-associated bloodstream infections in hemodialysis patients. Studies published from 1990 to 2011 have been selected through electronic search in the following databases: Cochrane Library,CINAHL, WEB OF SCIENCE, Medline, SciELO, Embase, Lilacs, works presented in congresses, reviews and guidelines. The search strategy used for Medline presented the following steps: .Catheterization, Central Venous. [Mesh] AND .Infection. [Mesh]) AND .Renal Dialysis. [Mesh]) AND .Renal Dialysis/education. [Mesh] AND .Infection Control. [Mesh]. To select articles, two independent reviewers assessed the titles and abstracts of the publications found. All studies in the issue meeting the criteria for review have been included regardless of the language or design. Photocopies of the articles have been obtained and a standard form has been used to extract data.

\section{Results}

Two hundred and ninety three articles were found according to the used descriptors, 50 of them were literature reviews. After a previous selection, we included some studies that met the inclusion criteria were selected according to the assessment of the two independent reviewers. Among the studies analyzed we included (chart 1) systematic reviews, prospective cohorts, experimental study, meta-analysis review, controlled randomized clinical essays, cross-sectional randomized clinical trial and guidelines.

It was clear that surveillance is the essential issue for an infection control program and also for improving quality of care. A prospective study carried out in London between 2002 and 2004 with 112 patients (3418 patients per month) demonstrated reduction in bacteremia rate from $6.2 \%$ to $2.0 \%$ per month, reduction in hospitalizations due to bacteremia from $4.0 \%$ to $1.4 \%$ per month and also a significant downward trend was seen in bacteremia rates and antibiotic usage after the introduction of a surveillance scheme with patients. risk stratification, definition of denominators, type of access performed by physicians and nurses from the service, team training, preventive measures of infections, dissemination of data and use of results to optimize the actions introduced (George A et al, 2006). The training and education of health professionals, patients and care givers is recommended by the Center for Disease Control and Prevention (CDC) to prevent dialysis infections and must be compatible with the available knowledge from the personnel involved ${ }^{(9)}$. A study conducted in a university hospital from São Paulo demonstrated $40 \%$ reduction in catheter-associated bloodstream infections (CABSI) after the implementation of an educational intervention with staff members (Lobo RD et al, 2005)

There are some standard precautions based on strategies to prevent transmission of infections that health professionals must use in patients. care: hand washing before and after 


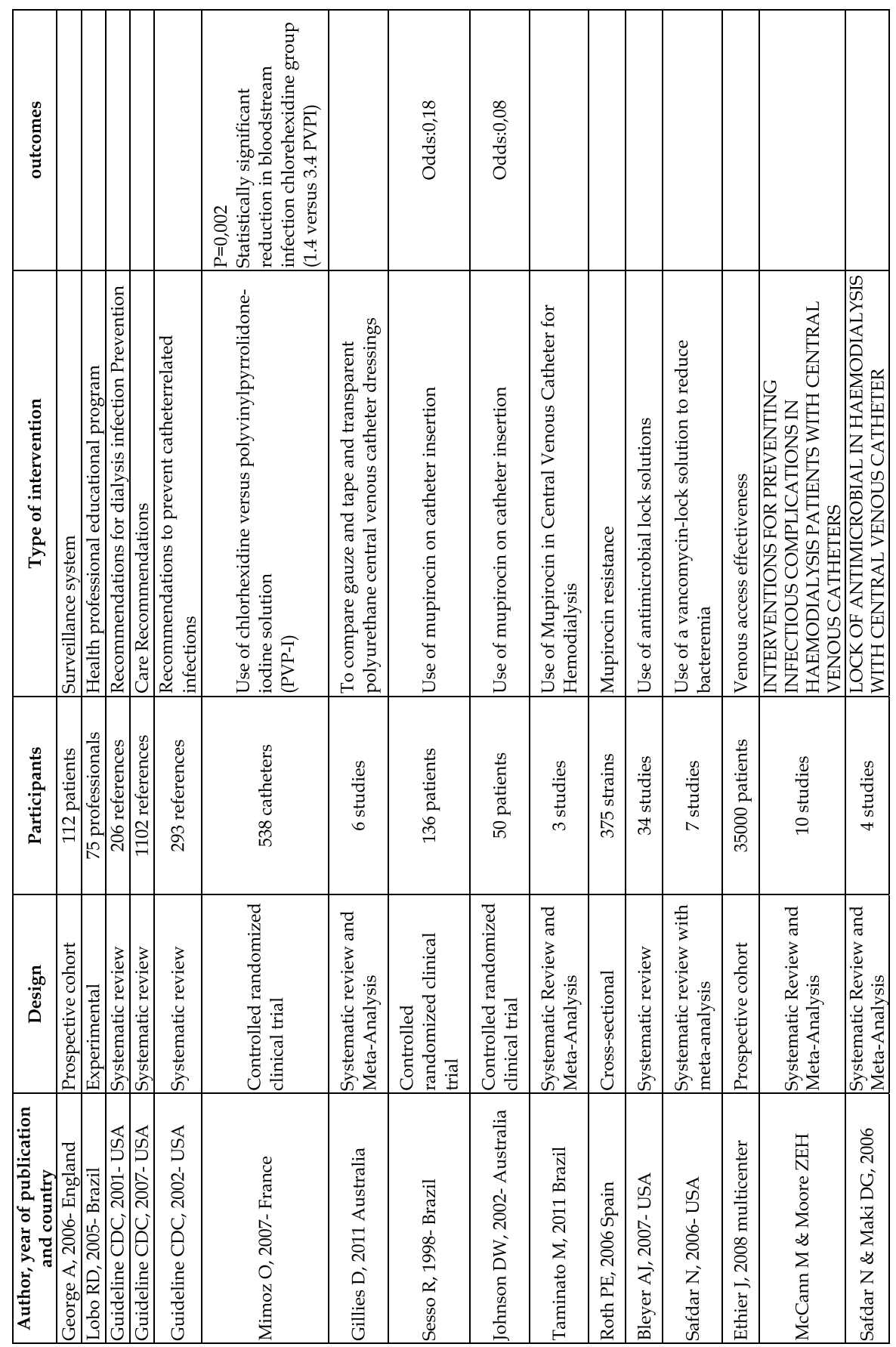

Chart 1 . Summary of the studies included 
the contact, use of gloves, masks, protection glasses and laboratory coats when there is risk of contact with biological material, be careful with sharp-edged and hollow-pointed devices, environmental cleaning, adequate use of materials and equipments and health professionals immunization. When patients present suspicion or confirmation of a more severe infection, additional measures must be taken in addition to those mentioned above (Ethier $\mathrm{J}$ et al 2008). According to national and international recommendations, catheter insertion has to be conducted under sterile conditions and maximum barrier: masks, laboratory coats, gloves and sterile drapes (Descamps-Latscha B \& Herbelin A, 1993; MMWR 2001; O.Grady NP et al, 2002). Alcoholic chlorhexidine $2 \%$ (drug of choice) or polyvinylpyrrolidone-iodine solution (PVP-I) 10\% has to be used for skin antisepsis before catheter insertion and before dressing changes (MMWR, 2001; Mimoz O et al, 2007).

A CVC can be non-tunnelled or tunnelled. A non-tunnelled catheter - sometimes referred to in the literature as non-cuffed, temporary, short-term or acute - is intended for shortterm haemodialysis use. On the other hand tunnelled catheters - also known as cuffed, chronic, long-term or permanent catheters - are generally used when patients require more than two to three weeks haemodialysis (Frankel, 2006). However, the reported use of these different catheters suggest that tunnelled catheters have been used for periods of short duration and, although not recommended, non-tunnelled catheters have been used for periods of long duration (months or years) (Ash SR, 2001; KDOQI 2006; Oliver MJ 2001; Ponikvar R, 2005).

A Cochrane systematic review with meta-analysis, published in 2003 compared the use of gauze and micropore film versus sterile transparent semipermeable polyurethane (Opsite ${ }^{\circledR}$ (Smith \& Nephew Healthcare Ltd), Tegaderm ${ }^{\circledR}(3 \mathrm{M})$ and Opsite IV3000 $\left.{ }^{\circledR}\right)$ to cover the catheter central venous. The transparent film covers so classified as highly permeable and permeable polyurethane polyurethane. The outcomes analyzed in this review were: catheter-related sepsis, infection at the catheter insertion site and colonization of catheter between the different types of coverage, but there was no statistical difference in any outcome analysis. One of the observations made by the plaintiff was an insufficient number of randomized clinical trials that could be included in the study (Gillies D et al, 2003)

A randomized study(Sesso $\mathrm{R}$ et al, 1998) highlighted that use of chlorhexidine before catheter insertion and during dressing changes is associated with less colonization and occurrence of CABSI when compared to the use of alcoholic PVP-I. Gauze or sterile transparent film are recommended to dress the site of catheter insertion. After bathing or showering it is important to inspect the insertion site, protecting it and replacing the catheter-site dressing when it becomes damp, loosened, or soiled (Descmaps-Latscha B \& Herbelin A,1993; MMWR 2001; Ethier et al, 2008). A study (Sesso R et al 1998) demonstrated that mupirocin use in the catheter insertion site reduces significantly the risk of $S$ aureus colonization and bacteremia. The same result was obtained in a study carried out in Australia (Johnson DW et al 2.002).

The meta-analysis of a profhylatic use of Mupirocin in central venous catheter for hemodialysis indicates that the use of topical mupirocin has been effective to reduce episodes of infections among patients increasing the usage time of the catheter in addition to significantly reducing the infections by $S$ aureus, the most prevalent in this population (Taminato $\mathrm{M}$ et al, 2011). 
Other systematic review (McCann M \& Moore ZEH, 2008) shws that topical antimicrobial ointments compared to no ointment or placebo had a significant favourable effect on catheter removal due to infection caused by all types of organisms ( RR 0.35, 95\% CI 0.25 to 0.50). Catheter removal due to $S$. aureus was significantly reduced by topical antimicrobial.

However, the emergence of resistant strains must be considered as demonstrated in a Spanish study where pandemia of methicillin-resistant Staphylococcus aureus was associated to high-level mupirocin resistance (Johnson et al, 2002; Perez-Roth E et al, 2006).

Another prevention strategy is the use of gentamicin, cephalosporin or vancomycin lock solution, taking into account the possibility of the emergence of resistant microorganisms when vancomycin is used (Bleyer AJ, 2007; Safdar N \& Maki DG, 2006).

The study Al-Kwiesh \& Abdulla Khalaf, showed that the administration of vancomycin catheter lock via intralumenal was superior compared to the peripheral intravenous administration, where the results showed that the experimental group of 28 patients that used the vancomycin catheter lock had only one $(3 \%)$ catheter removal, in contrast, the control group of 39 patients that had peripheral intravenous antibiotics had $22(56 \%)$ catheter removals.

In a meta-analysis, authors demonstrated that in highrisk patients treated with long-term catheters the use of vancomycin lock solution reduces the risk of bacteremia(Safdar N \& Maki DG, 2006). CDC does not recommend the regular use of antimicrobial lock solution to prevent bloodstream infection. The use is recommended only in special circumstances (e.g. patient with a long-term catheter or patients with clinical data of recurrent infections despite optimal maximal adherence to aseptic technique (O’Grady et al, 2002).

\section{Conclusion}

The authors conducted extensive review to suggest that catheter-associated bloodstream infection can be reduced when prevention measures are adequately taken they are: proper choice of insertion site, local antisepsis, personnel appropriate attire, infection surveillance, care and maintenance of the catheter or remove as well as the use of new technologies. Topical mupirocin ointment significantly reduced the risk of $S$. aureus exit site infection and catheter-related bacteraemia. The risk of catheter removal and episodes of hospitalisation due to $S$. aureus were also significantly reduced in those patients who used topical mupirocin ointment. Taking into account that this is a population at high risk for infection, the emergence of multi-resistant microorganisms must be considered, and if a severe case occurs, additional prevention measures must be taken to avoid an outbreak in this population. All personnel involved in the process of catheter insertion, maintenance and removal must be aware of the importance of excellent care for infection prevention therefore this chapter may contribute to infection control book.

\section{Acknowledgment}

We thank the research groups of Nephrology Nursing UNIFESP-Group and the systematic review and meta-analysis of the, UNIFESP.

We thank of Cochrane Brazil Colaboration. 


\section{References}

[1] Adem PV, Montgomery CP, Husain AN, Koogler TK, Arangelovich V, Humilier M, et al. Staphylococcus aureus sepsis and the Waterhouse-Friderichsen syndrome in children. N Engl J Med. 2005; 353: 1245-1251.

[2] Al-Hwiesh AK, Abdul-Rahman IS. Successful Prevention of Tunneled, Central Catheter Infection by Antibiotic Lock Therapy Using Vancomycin and Gentamycin. Saudi J Kidney Dis Transpl [serial online] 2007 [cited 2011 Aug 16];18:239-47.

[3] Arthur M, P Courvalin. Genetics and mechanism of glycopeptide resistance in enterococci. Antimicrob Agents Chemother 1993; 37(8): 1563- 1571.

[4] Ash SR. The evolution and function of central venous catheters for dialysis. Seminars in Dialysis 2001;14:416-24.

[5] Barbosa D, Lima L, Silbert S, Sader H, Cendoroglo M, Draibe S et al. Evaluation of the prevalence and risk factors for colonization by vancomycin-resistant Enterococcus among patients on Dialysis. Am J Kidney Dis 2004; 44: 337-343.

[6] Brady JP, Snyder JW, Hasbargen JA. Vancomycin-resistant Enterococcus inend-stage renal disease. Am J Kidney Dis. 1998; 32(3):415-8.

[7] Brasilian Society of Nefrology (SBN). National sense 2007 [Internet]. São Paulo: SBN; 2010. [link: 2011 September 19]. Acess: http://www.sbn.org.br/Censo/2010/ censo_SBN_2010.ppt

[8] Bleyer AJ. Use of Antimicrobial Catheter Lock Solutions to Prevent Catheter-Related Bacteremia. Clin J Am Soc Nephrol. 2007; 2: 1073-1078.

[9] Bocchini CE, Hulten KG, Mason EO, Jr., Gonzalez BE, Hammerman WA. (2006) PantonValentine leukocidin genes are associated with enhanced inflammatory response and local disease in acute hematogenous Staphylococcus aureus osteomyelitis in children. Pediatrics 117: 433-440.

[10] Butterly DW, Schwab SJ. Catheter access for hemodialysis: an overview. Seminars in Dialysis 2001;14:411-5.

[11] Chang S, Sievert DM, Hageman JC, Boulton ML, Tenover FC, Downes FP, et al. Brief report. Infection with vancomycin-resistant Staphylococcus aureus containing the vanA resistance gene. N Engl J Med 2003; 348(14):1324-1347.

[12] Cheng V C C, Li I W S, Wu A K L, Tang B S F, Ng K H L, To K K W, Tse H, Que T L, Ho P L, Yuen K Y. Effects of antibiotics on de bacterial load of meticillin-resistant Staphylococcus aureus colonisation in anterior nares. Journal of Hospital Infection. 2008; 70: 27-34.

[13] Clinical practice guidelines and clinical practice for vascular access, update 2006.

[14] Descamps-Latscha B, Herbelin A. Long-term dialysis and cellular immunity: a critical survey. Kidney Int Suppl. 1993;41:S135-42.

[15] Ethier J, Mendelssohn DC, Elder SJ, Hasegawa T, Akizawa T, Akiba T, et al. Vascular access use and outcomes: an international perspective from the Dialysis Outcomes and Practice Patterns Study. Nephrol Dial Transplant. 2008;23(10):3219-26. Erratum in: Nephrol Dial Transplant. 2008;23(12):4088.

[16] Fram D, Castrucci FM, Taminato M, Godoy-Martinez P, Freitas MC, Belasco A, Sesso R, Pacheco-Silva A, Pignatari AC, Barbosa D. Cross-transmission of vancomycinresistant Enterococcus in patients undergoing dialysis and kidney transplant. Braz J Med Biol Res. 2010; 43(1):115-9. 
[17] Frankel A. Temporary access and central venous catheters. European Journal of Vascular \& Endovascular Surgery 2006;31:417-22.

[18] Freitas MCS, Silva AP, Barbosa D, Silbert S, Sader H, Sesso R et al. Prevalence of vancomycin- resistant Enterococcus fecal colonization among kidney transplant patients. BCM Infectious Diseases 2006; 6:133.

[19] George A, Tokars JI, Clutterbuck EJ, Bamford KB, PuseyC, Holmes AH. Reducing dialysis associated bacteraemia, and recommendations for surveillance in the United Kingdom: prospective study. BMJ. 2006;332(7555):1435.

[20] Gilles D, Carr D, Frost J, O'Riordan R, O'Brien I. Gauze and tape and transparent polyurethane dressings for central venous catheters. Cochrane Database of Systematic Reviews 2003.

[21] Grothe C, Belasco A, Bettencourt A, Diccini S, Vianna L, Sesso R, Barbosa D. High incidence of bacteremia among patients undergoing hemodialydis. Rev Latinoam Enferm. 2009; 18 (1): (8 telas).

[22] Hörl WH. Neutrophil function and infections in uremia. Am J Kidney Dis. 1999;33(2):xlv.xlviii.

[23] Johnson DW, MacGinley R, Kay TD, Hawley CM, Campbell SB, Isbel NM, Hollett P. A randomized controlled trial of topical exit site mupirocin application in patients with tunnelled, cuffed haemodialysis catheters. Nephrol Dial Transplant. 2002;17(10):1802-7.

[24] Klevens RM, Edwards JR, Andrus ML, Peterson KD, Dudeck MA, Horan TC; NHSN Participants in Outpatient Dialysis Surveillance. Dialysis Surveillance Report: National Healthcare Safety Network (NHSN) - data summary for 2006. Semin Dial. 2008;21(1):24-8.

[25] King MD, Humphrey BJ, Wang YF, Kourbatova EV, Ray SM, et al. Emergence of community-acquired methicillin-resistant Staphylococcus aureus USA 300 clone as the predominant cause of skin and soft-tissue infections. Ann Intern Med. 2006; 144: 309-317.

[26] Letourneau I, Ouimet D, Dumont M, Pichette V, Leblanc M. Renal replacement in endstage renal disease patients over 75 years old. American Journal of Nephrology 2003;23:71-7.

[27] Lobo RD, Levin AS, Gomes LMB, Cursino R, Park M, Figueiredo VB, et al. Impact of an educational program and policy changes on decreasing catheter-associated bloodstream infections in a medical intensive care unit in Brazil. Am J Infect Control. 2005;33(2):83-7.

[28] Mangini C, Camargo LFA, coordenadores. Prevenção de infecção relacionada à diálise. São Paulo: APECIH - Associação Paulista de Estudos e Controle de Infecção Hospitalar; 2005.

[29] Mason J, Khunti K, Stone M, Farooqi A, Carr S. Educational Interventions in Kidney Disease Care: A systematic review of randomized trials. Am J of Kidney Dis. 2008;51(6):933-51.

[30] Mendelssohn DC, Ethier J, Elder SJ, Saran R, Port FK, Pisoni RL. Haemodialysis vascular access problems in Canada: results from the dialysis outcomes and practice patterns study (DOPPS II). Nephrology Dialysis Transplantation 2006;21:721-8.

[31] McCann M \& Moore ZEH. Interventions for preventing infectious complications in haemodialysis patients with central venous catheters. Cochrane Database of 
Systematic Reviews. In: The Cochrane Library, Issue 08, Art. No. CD006894. DOI: 10.1002/14651858.CD006894.pub1

[32] Mimoz O, Villeminey S, Ragot S, Dahyot-Fizelier C, Laksiri L, Petitpas F, Debaene B. Clorhexidine-based antiseptic solution vs alcohol-based povidone-iodine for central venous catheter care. Arch Intern Med. 2007;167(19):2066-72.

[33] Moore C, Dhaliwal J, Tong A, Eden S, Wigston C, Willey B, McGeer A. Risk factors for methicillin-resistant Staphylococcus aureus (MRSA) acquisition in roommate contacts of patients colonized or infected with MRSA in an acute-care hospital. Infect Control Hosp Epidemiol. 2008;29:600-606.

[34] O.Grady NP, Alexander M, Dellinger EP, Gerberding JL, Heard SO, Maki DG, et al. Guidelines for the prevention of intravascular catheter-related infections. Centers for Disease Control and Prevention. MMWR Recomm Rep. 2002;51(RR-10):1-29.

[35] Oliver MJ. Acute dialysis catheters. Seminars in Dialysis 2001;14:432-5.

[36] Pérez-Roth E, López-Aguilar C, Alcoba-Florez J, Méndez-Alvarez S. High-level mupirocin resistance within methicillin-resistant staphylococcus aureus pandemic lineages. Antimicrob Agents Chemother. 2006;50(9):3207-11.

[37] Perencevich EN, Fisman DN, Lipsitch M, Harris AD, Morris JG Jr, Smith DL. Projected benefits of active surveillance for vancomycin-resistant enterococci inintensive care units. Clin Infect Dis. 2004; 15 38(8):1108-15.

[38] Ponikvar R. Hemodialysis catheters. Therapeutic Apheresis \& Dialysis: Official PeerReviewed Journal of the International Society for Apheresis, the Japanese Society for Apheresis, the Japanese Society for Dialysis Therapy 2005;9:218-22.

[39] Recommendations for preventing transmission of infections among chronic hemodialysis patients. MMWR Recomm Rep. 2001;50(RR-5):1-43.

[40] Rhee JY, Park KY, Shin JY, Choi JY, Lee MY,Peck KR et al. KPC-producing extreme drug-resistant Klebsiella pneumoniae isolate from a patient with diabetes mellitus and chronic renal failure on hemodialysis in South Korea. Agents Chemother. 54;(5):2278-9, 2010.

[41] Roberts S, West T, Morris A. Duration of methicillin-resistant Staphylococcus aureus colonization in hospitalised in patients. New Zeland Medical Journal. 2004; 117: 1195.

[42] Salgado CD, Farr BM. Outcomes associated with vancomycin-resistant enterococci: a meta-analysis. Infect Control Hosp Epidemiol. 2003; 24(9):690-8.

[43] Safdar N, Maki DG. Use of vancomycin-containing lock or flush solutions for prevention of bloodstream infection associated with central venous access devices: a meta-analysis of prospective, randomized trials. Clin Infec Dis. 2006;43(4):474-84.

[44] Sesso R, Barbosa D, Leme IL, Sader H, Canziani ME, Manfredi S, et al. Staphylococcus aureus prophylaxis in hemodialysis patients using central venous catheter: effect of mupirocin ointment. J Am Soc Nephrol. 1998;9(6):1085-92.

[45] Siegel JD, Rhinehart E, Jackson M, Chiarello L, Healthcare Infection Control Practices Advisory Committee. 2007 Guideline for Isolation Precautions: Preventing Transmission of Infectious Agents in Healthcare Settings [Internet]. CDC; 2007. [cited 2011 september 12]. Available from: http://www.cdc.gov/ncidod/dhqp/pdf/isolation2007.pdf

[46] Taminato M, Fram DS, Groethe C, Belasco A, Barbosa DA. Prophilatic Use of Mupirocin in Central Venous Catheter for Hemodialysis: Systematic Review and MetaAnalysis. Acta Paulista de Enfermagem. 2012 : 25 (1):(in press). 
[47] Tokars JI, Frank M, Alter MJ, Arduino MJ. National surveillance of dialysis-associated diseases in the United States, 2000. Semin Dial. 2002; 15(3):162-71.

[48] U.S. Renal Data System, USRDS 2006 Annual Data Report: Atlas of End-Stage Renal Disease in the United States, National Institutes of Health, National Institute of Diabetes and Digestive and Kidney Diseases, Bethesda, MD, 2006.

[49] U.S. Renal Data System, USRDS 2008 Annual Data Report: Atlas of Chronic Kidney Disease and End-Stage Renal Disease in the United States, National Institutes of Health, National Institute of Diabetes and Digestive and Kidney Diseases, Bethesda, MD, 2008.

[50] U.S. Renal Data System, USRDS 2010 Annual Data Report: Atlas of Chronic Kidney Disease and End-Stage Renal Disease in the United States, National Institutes of Health, National Institute of Diabetes and Digestive and Kidney Diseases, Bethesda, MD, 2010.

[51] Wertheim HF, Vos MC, Ott A, van Belkum A, Voss A, Kluytmans J, et al. Risk and outcome of nosocomial Staphylococcus aureus bacteraemia in nasal carriers versus non-carriers. Lancet 2004 364: 703-705.

[52] Werner G, Coque TM, Hammerum AM, Hope R, Hryniewicz W, Johnson A, et al. Emergence and spread of vancomycin resistance among enterococci in Europe. Euro Surveill. 2008; 13: 1-11.

[53] Van Belkum A, Verkaik NJ, de Vogel CP, Boelens HA, Verveer J. Reclassification of Staphylococcus aureus nasal carriage types. J Infect Dis. 2009; 199:1820-1826.

[54] Von Eiff C, Becker K, Machka K, Stammer H, Peters G. Nasal carriage as a source of Staphylococcus aureus bacteremia. Study Group. N Engl J Med. 2001; 344: 11-16. 


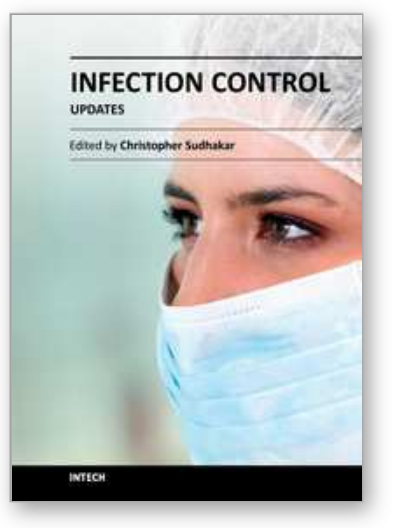

\author{
Infection Control - Updates \\ Edited by Dr. Christopher Sudhakar
}

ISBN 978-953-51-0055-3

Hard cover, 198 pages

Publisher InTech

Published online 22, February, 2012

Published in print edition February, 2012

Health care associated infection is coupled with significant morbidity and mortality. Prevention and control of infection is indispensable part of health care delivery system. Knowledge of Preventing HAI can help health care providers to make informed and therapeutic decisions thereby prevent or reduce these infections.

Infection control is continuously evolving science that is constantly being updated and enhanced. The book will be very useful for all health care professionals to combat with health care associated infections.

\title{
How to reference
}

In order to correctly reference this scholarly work, feel free to copy and paste the following:

Dulce Barbosa, Mônica Taminato, Dayana Fram, Cibele Grothe and Angélica Belasco (2012). Prevention of Catheter-Related Bloodstream Infections in Patients on Hemodialysis, Infection Control - Updates, Dr. Christopher Sudhakar (Ed.), ISBN: 978-953-51-0055-3, InTech, Available from:

http://www.intechopen.com/books/infection-control-updates/prevention-of-infection-on-venous-catheter-inhemodialysis-a-systematic-review

\section{INTECH}

open science | open minds

\section{InTech Europe}

University Campus STeP Ri

Slavka Krautzeka 83/A

51000 Rijeka, Croatia

Phone: +385 (51) 770447

Fax: +385 (51) 686166

www.intechopen.com

\section{InTech China}

Unit 405, Office Block, Hotel Equatorial Shanghai

No.65, Yan An Road (West), Shanghai, 200040, China

中国上海市延安西路65号上海国际贵都大饭店办公楼 405 单元

Phone: +86-21-62489820

Fax: $+86-21-62489821$ 
(C) 2012 The Author(s). Licensee IntechOpen. This is an open access article distributed under the terms of the Creative Commons Attribution 3.0 License, which permits unrestricted use, distribution, and reproduction in any medium, provided the original work is properly cited. 